\title{
Application of the Beremin Model for Cruciform Specimen to Determine the Fracture Probability in Case of WPS
}

\author{
R. Beleznai and Sz. Szavai
}

Bay Zoltan Nonprofit Ltd., Institute for Logistics and Production Systems, Miskolc, Hungary

УДК 539.4

\section{Оценка вероятности разрушения крестообразных образцов в случае горячей опрессовки по модели Беремина}

\section{Р. Белезнаи, Ш. Шаваи}

Бай Золтан Лтд., Институт логистики и производственных систем, Мишкольц, Венгрия

С использованием результатов экспериметальных иссследований крупногабаритных крестообразных образцов из реакторной стали франиузского производства выполнено конечноэлементное моделирование эффекта горячей опрессовки при ииклической нагрузке по схемам: нагрузка-охлаждение-разрушение и нагрузка-охлаждение-переходный проиесс-разрушение. Для оценки вероятности разрушения образиов использована модифицированная модель Беремина.

Ключевые слова: крестообразный образец, метод конечных элементов, модифицированная модель Беремина.

Introduction. In the framework of NESC VII European project, large-scale experimental tests have been performed on cruciform specimens made of French type RPV steel under different loading and temperature conditions to study the warm prestressing (WPS) effect. Several European industrial partners and research institutes participate in the project (EDF, CEA, AREVA NP France, AREVA GmbH, NRI, AEKI-KFKI, SCK-CEN, INSPECTA, IWM, TWI, SERCO, Bristol University, etc.). The experimental tests were conducted by CEA in France. LCF (load-cool-fracture) and LCTF (load-cool-transient-fracture) load cycles are considered during the analyses. The purpose of this paper is to review recent research into the WPS effect in different testing configurations by numerical calculation simulating the experimental tests. Five specimens of similar type, but with different crack dimensions, were tested and separate finite element (FE) models were created for them according to the crack geometry (Table 1). The experiments have been performed on large-scale cruciform specimens with a semi-elliptical crack (Fig. 1).

1. Geometry Description. The thickness and length of the specimen are $98 \mathrm{~mm}$ and $840 \mathrm{~mm}$, respectively. The applied finite element software is the MSC.MARC 2010. The model contains 39,520 eight-node solid elements and 45,726 nodes. The four slots and the crack are modeled with sharp edges. Only one quarter of the 


T a b 1 e 1 Crack Dimensions
\begin{tabular}{|c|c|c||}
\hline \hline Test No. & $a, \mathrm{~mm}$ & $2 c, \mathrm{~mm}$ \\
\hline Test 1 & 12.0 & 35.0 \\
\hline Test 2 & 12.8 & 36.5 \\
\hline Test 3 & 12.3 & 36.0 \\
\hline Test 4 & 12.2 & 36.0 \\
\hline Test 5 & 12.2 & 36.0 \\
\hline
\end{tabular}
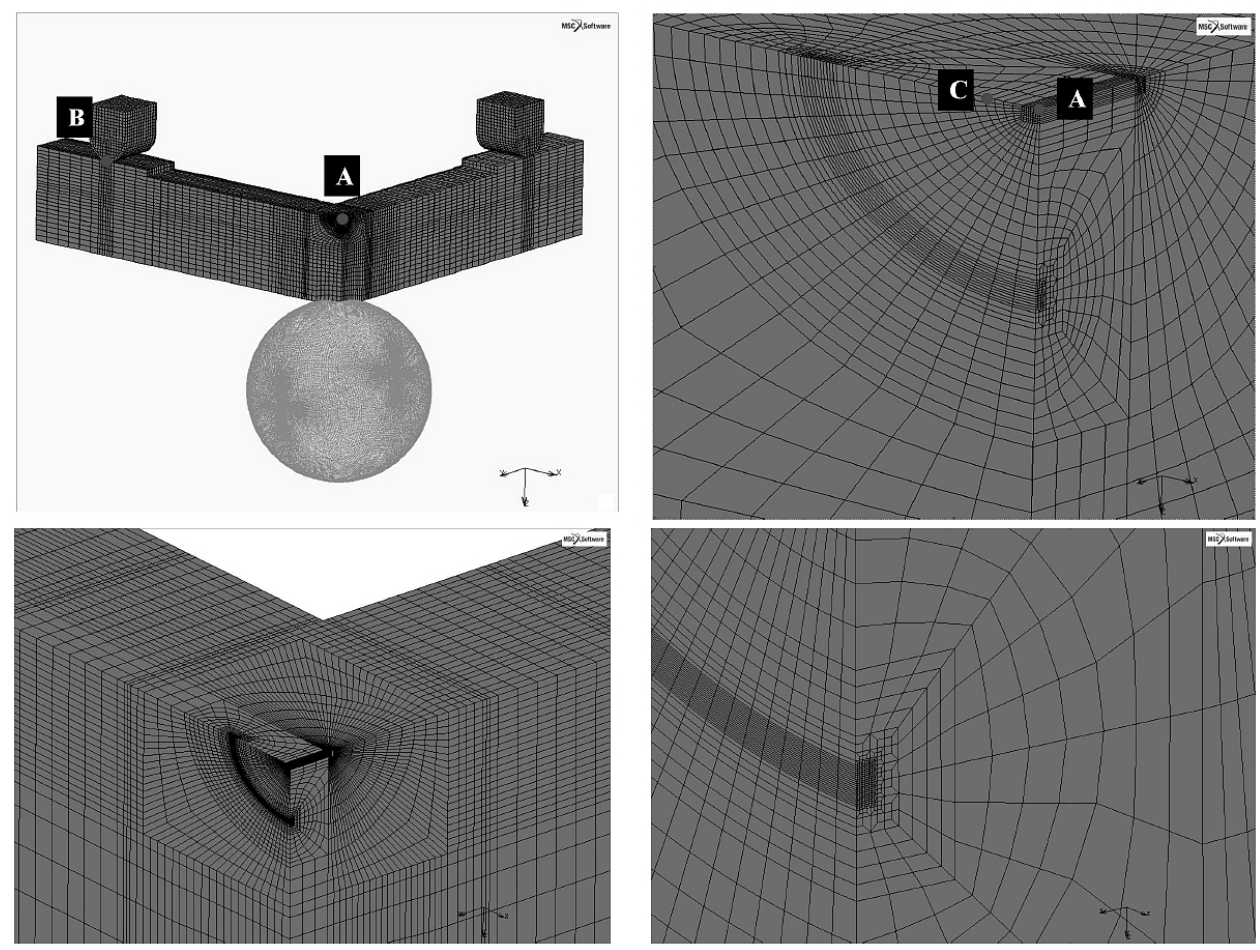

Fig. 1. Mesh of the specimens.

specimen is modeled. Type of the discretization of the support and the ball is analyzed, and finally the supports of the specimen are modeled as elastic solids and the sphere is defined as a rigid surface. The size of the mesh around the crack tip is $50 \times 50 \mu \mathrm{m}$ complying with the requirement in [1].

2. Material Description. The specimens are made of 18MND5 ferritic steel (A533B). Temperature dependent elastic-plastic material properties with isotropic hardening law are assumed for the calculation. Elastic-plastic analysis for determination of the crack driving force ( $J$-integral) is performed using MSC.MARC 2010 FE code. The stress-strain curves used in the analyses are shown in Fig. 2.

3. Loading Path. The loading paths, which are imposed to the specimens, are the LCF (for Tests 1 and 2) and LCTF (Tests 3, 4, and 5) type of thermo mechanical transient. Main parameters of these loading transients are given in Table 2. The 
$\mathrm{T}$ a b 1 e 2

Parameters of the Loading Transients for Different Load Cycles

\begin{tabular}{||c|c|c|c|c|c|c||}
\hline Test No. & WPS cycle & $T_{\text {preload }},{ }^{\circ} \mathrm{C}$ & $T_{\text {unload }},{ }^{\circ} \mathrm{C}$ & $T_{\text {fract }},{ }^{\circ} \mathrm{C}$ & $F_{\text {WPS }}, \mathrm{kN}$ & $F_{\text {unload }}, \mathrm{kN}$ \\
\hline Test 1 & LCF & -33.6 & -110.0 & -150 & 1328.8 & - \\
\hline Test 2 & LCF & -32.5 & -110.0 & -150 & 1328.8 & - \\
\hline Test 3 & LCTF & -35.0 & -110.0 & -150 & 1280.0 & 570 \\
\hline Test 4 & LCTF & -29.5 & -110.0 & -150 & 1280.0 & 570 \\
\hline Test 5 & LCTF & -30.5 & -110.5 & -150 & 1280.0 & 70 \\
\hline
\end{tabular}

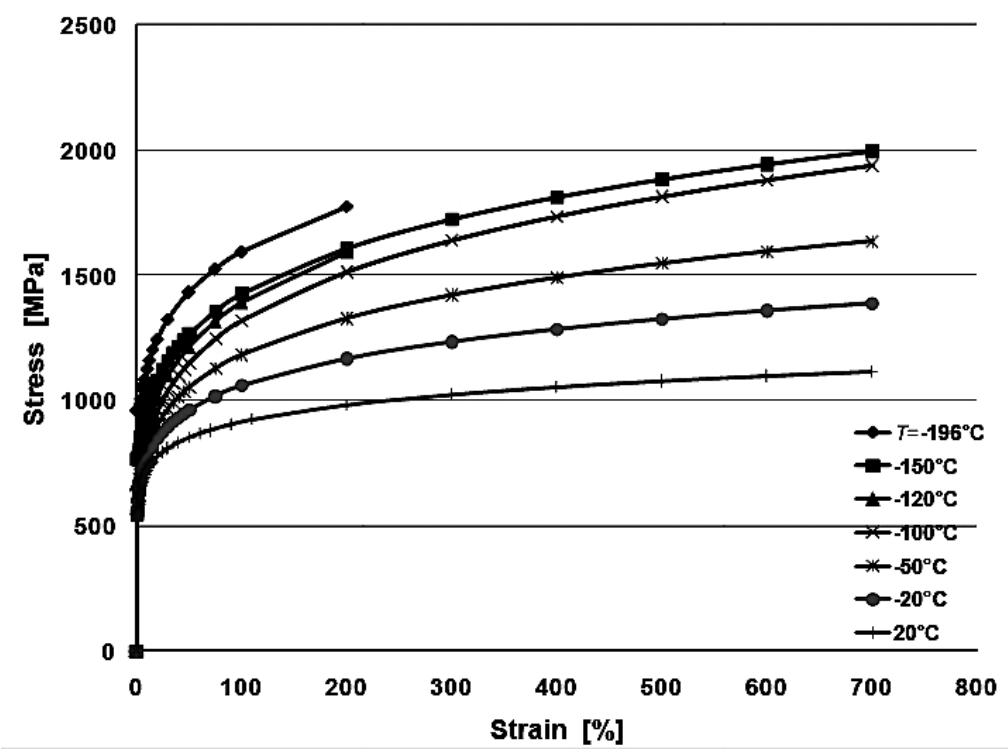

Fig. 2. Stress-strain curves for 18MND5 material.

loading path of the LCF tests involves the following stages: an isothermal preloading up to WPS load (at about $K_{J_{-W P S}} \approx 80 \mathrm{MPa} \sqrt{\mathrm{m}}$ ), then cooling down under constant mechanical load and, finally, the isothermal fracture loading at a considerably lower temperature than the preload. In case of the LCTF cycle between the cooling and fracture phase there is a transient load, where the temperature and the mechanical load decrease at the same time. All geometry, material and loading data as well as characteristics were provided by the AREVA NP and CEA. The results of the experimental tests for LCF load cycle were used for verification of the finite element model, and benchmark analyses of the LCTF load cycle have been performed to predict the fracture moment and failure probability.

4. Validation of the Finite Element Models. The obtained results are compared with the available experimental test results, but the comparison is presented only for Test 4 configuration. The load-deflexion curve is shown in Fig. 3. The deflexion is obtained from the displacement difference between points $A$ and $B$ (Fig 1.) The load-CMOD diagram contains three CMOD curves (Fig. 4), one represents the experimental test, and the others belong to FE results. One of the FE curves presents the CMOD curve in the midpoint (point $A$ in Fig. 1) of the crack 


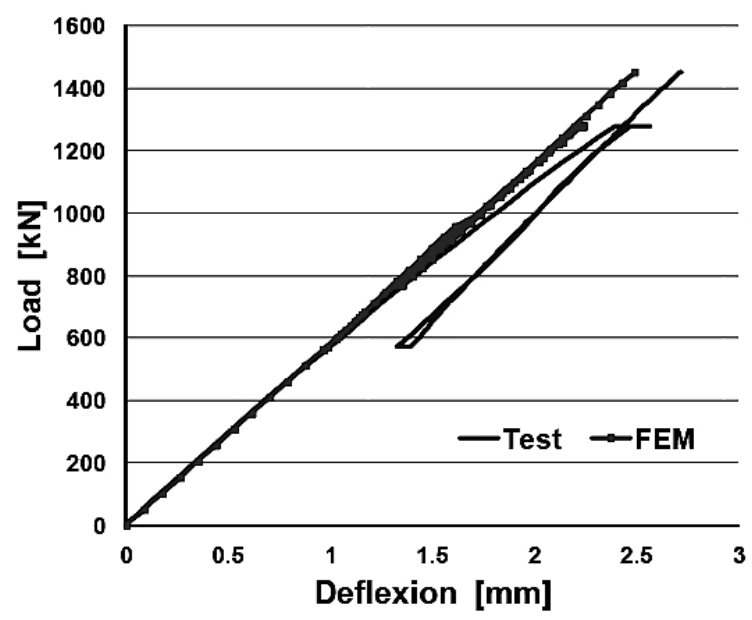

Fig. 3. Load-deflexion curve for the cruciform specimen.

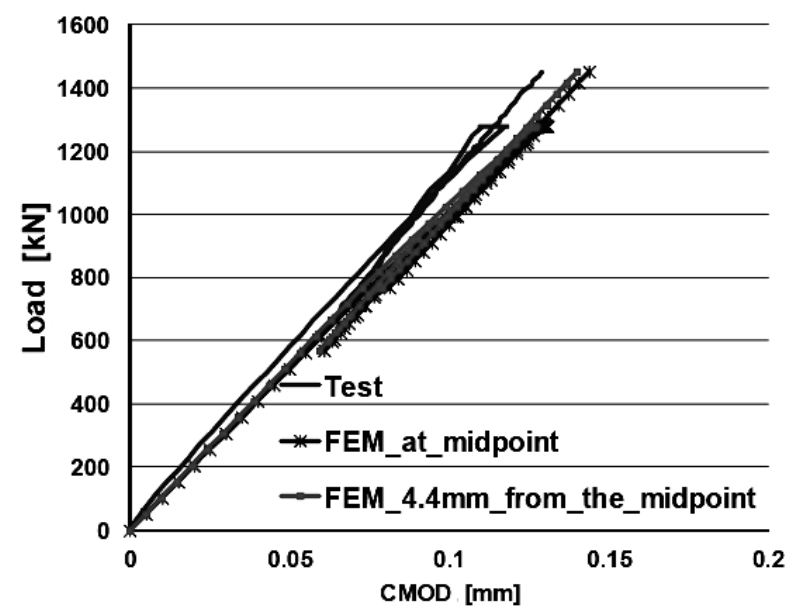

Fig. 4. Load-CMOD curve for the cruciform specimen.

mouth, the other curve is the corrected result: the clip gauge has a certain width $(10 \mathrm{~mm})$ and because of this the CMOD cannot be measured at the widest point of the opened crack mouth (point $A$ in Fig. 1). That is why $5 \mathrm{~mm}$ from the crack symmetry plane the CMOD should be post-processed (point $C$ in Fig. 1). The mesh contains nodes only at a distance of 4.4 and $5.5 \mathrm{~mm}$ from the symmetry plane, thus, CMOD is plotted in the node at a distance of $4.4 \mathrm{~mm}$ from the centre. The temperature-CMOD curve is presented in Fig. 5 and the temperature- $K_{J}$ curves are seen in Fig. 6, where the CMOD curve is obtained from $A$ and $C$ points (Fig. 1). The curves of the FE results are in good agreement with the test curves. In case of the load-deflexion curve the compliance and the thermal expansion of the testing machine are taken into account. The $K_{J}$ values are obtained from converting $J$ to $K_{J}$ assuming plane strain conditions and using the following expression:

$$
K_{J}=\sqrt{\frac{E J}{1-v^{2}}} \quad[\mathrm{MPa} \sqrt{\mathrm{m}}] .
$$




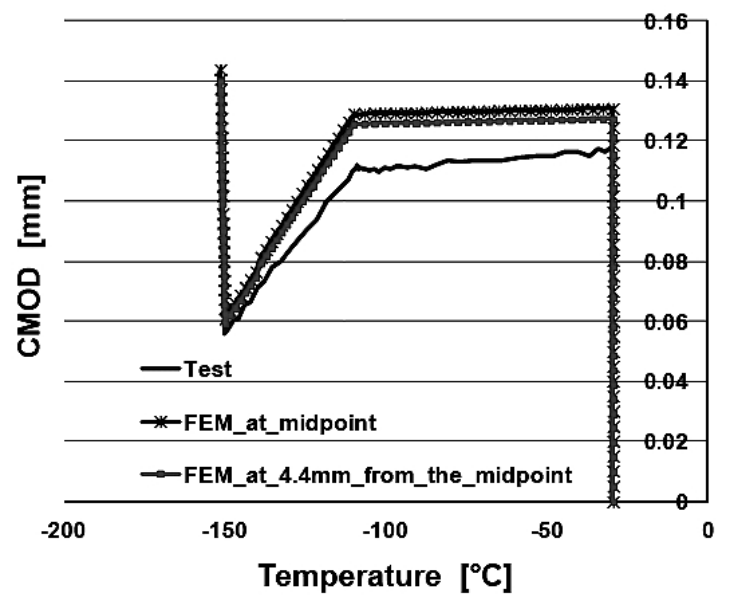

Fig. 5. Temperature-CMOD curve for the cruciform specimen.

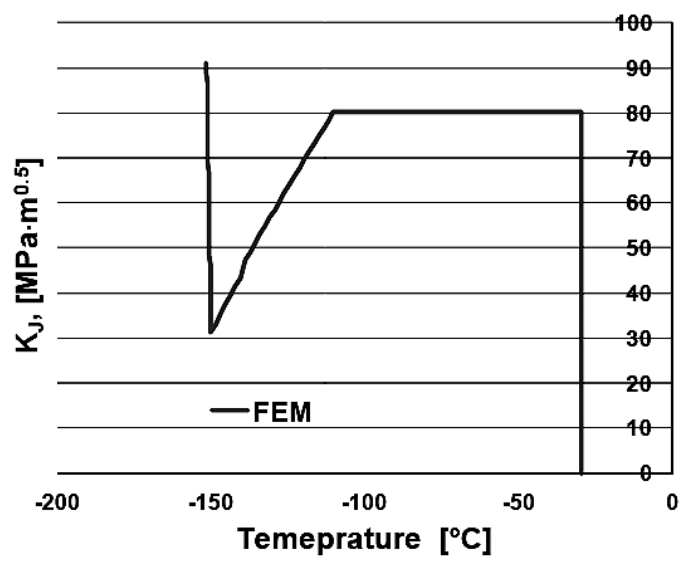

Fig. 6. Temperature- $K_{J}$ curve for the cruciform specimen.

Figure 7 presents the variation of the crack driving force $K_{J}$ along the crack front for two load levels (primary loading and fracture load). Here, $\Theta=0$ is the location on the free surface and $\Theta=90^{\circ}$ at the deepest point of the crack. It is observed that the maximum $K_{J}$ occurs at a location of around $\Theta=11.75^{\circ}$ for Test 1 and $\Theta=12.01^{\circ}$ for Test 2 degrees along the crack front.

5. Modified Beremin Model. For determination of the fracture moment and failure probability the modified Beremin model was used [1]. Under this complex loading path, the so-called active plastic zone, which is varying during loading, should be determined. The total equivalent plastic strain criterion was used for defining the active plastic zone during unloading and fracture stage similarly as in [2]. This criterion is different from the one described in [1]. The plastic zone includes points where the $\varepsilon_{p}>0.002$ ( $\varepsilon_{p}$ is the total equivalent plastic strain). To determine the cumulative probability of failure, the following expression was used

$$
P_{r}=1-\exp \left(-\int_{\Omega}\left(\max _{\{u \leq 1, \dot{p}(u)>0\}} \frac{\sigma_{1}(u)}{\sigma_{u}(\theta(u))}\right)^{m} \frac{d V}{V_{0}}\right),
$$




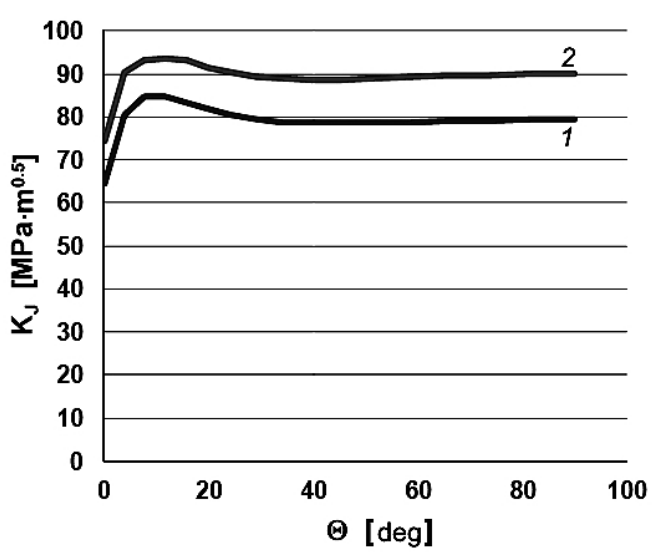

Fig. 7. Value of $K_{J}$ along the elliptical curve of the crack front at different load levels: (1) $F=$ $=1280 \mathrm{kN}$; (2) $F=1453.6 \mathrm{kN}$.

where $\sigma_{1}(u)$ is the maximum principal stress at instant $t, p(u)$ is the cumulated plastic deformation, and $\sigma_{u}(\theta)$ is the cleavage characteristic stress, which can depend on the temperature $\theta$.

The active plastic zone criterion for unloading and reloading stages is

$$
\varepsilon_{p_{-} a c t u a l}-\varepsilon_{p_{-} 0}>0
$$

where $\varepsilon_{p_{-} 0}$ is $\varepsilon_{p}$ at the end of the preloading stage and $\varepsilon_{p}$ actual is the $\varepsilon_{p}$ at the actual point of the unloading or fracture stage. The applied Beremin parameters are given in Table 3 .

T a b 1 e 3

The Beremin Parameters

\begin{tabular}{|c|c|c|c|c|c||}
\hline \hline$m$ & \multicolumn{5}{|c|}{23.43} \\
\hline$\theta,{ }^{\circ} \mathrm{C}$ & -150 & -100 & -50 & -20 & 20 \\
\hline$\sigma_{u}, \mathrm{MPa}$ & 2736 & 2007 & 3161 & 3421 & 4200 \\
\hline
\end{tabular}

The software is developed in FORTRAN language for selection of the elements in the process zone, which contains Gauss points according to the active plastic zone criterion. With this software, the Weibull stress and the cumulative failure probability are determined using the above mentioned expressions. Table 4 provides a summary about the $K_{J}$ values at different stages of the loading paths and the predicted failure probabilities. Based on the obtained results, the failure probability-load curves are plotted (Fig. 8). In case of the Test 5, the fracture probability is determined without knowing the experimental fracture force. The purpose of this analysis was to estimate the application of the modified Beremin model to determine the failure probability.

To determine the fracture moment, the failure probability is calculated in several points during reloading, and fracture is assumed to occur where the failure probability is higher than 0.99 . Fracture was predicted at a load of $F=1230 \mathrm{kN}$, at 
T a b 1 e 4

Values of $K_{J}$ and $P_{r}$ Relating to the Crack Deepest Point

\begin{tabular}{|c|c|c|c|c|c||}
\hline Test No. & WPS cycle & $\begin{array}{c}K_{J_{-} W P S}, \\
\mathrm{MPa} \sqrt{\mathrm{m}}\end{array}$ & $\begin{array}{c}K_{J_{-} \text {unload }}, \\
\mathrm{MPa} \sqrt{\mathrm{m}}\end{array}$ & $\begin{array}{c}K_{J_{-} \text {fract }}, \\
\mathrm{MPa} \sqrt{\mathrm{m}}\end{array}$ & $P_{r}$ \\
\hline Test 1 & LCF & 81.97 & - & 92.20 & 0.9999 \\
\hline Test 2 & LCF & 82.94 & - & 92.76 & 0.9999 \\
\hline Test 3 & LCTF & 79.11 & $\sim 30.90$ & 79.88 & 0.1369 \\
\hline Test 4 & LCTF & 79.34 & $\sim 30.09$ & 89.97 & 0.9999 \\
\hline Test 5 & LCTF & 80.22 & 0 & 77.02 & 0.9998 \\
\hline
\end{tabular}

Test 1

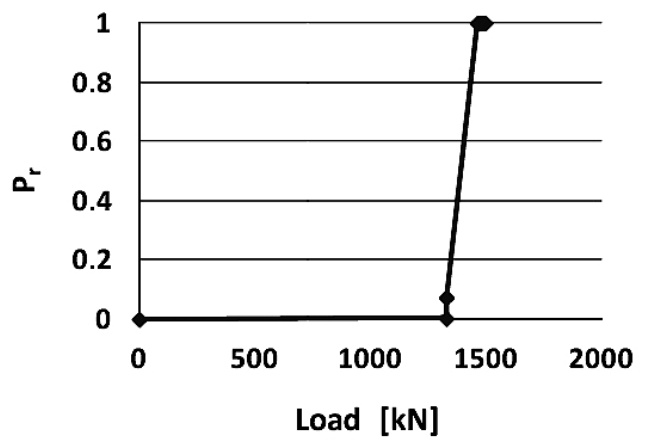

Test 3

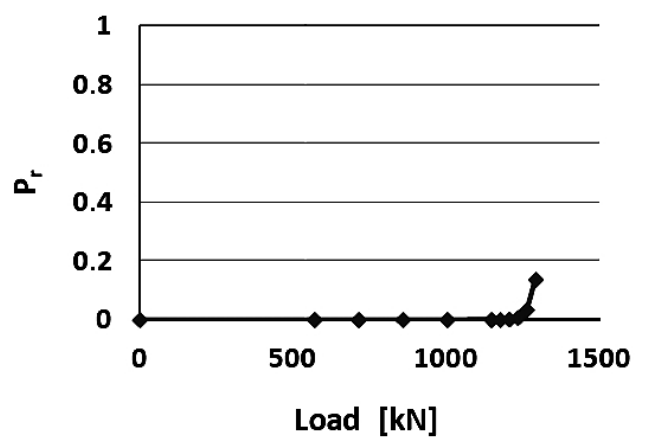

Test 2

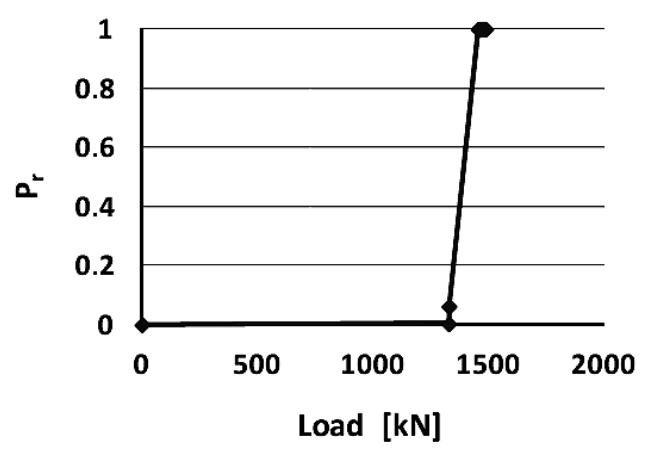

Test 4

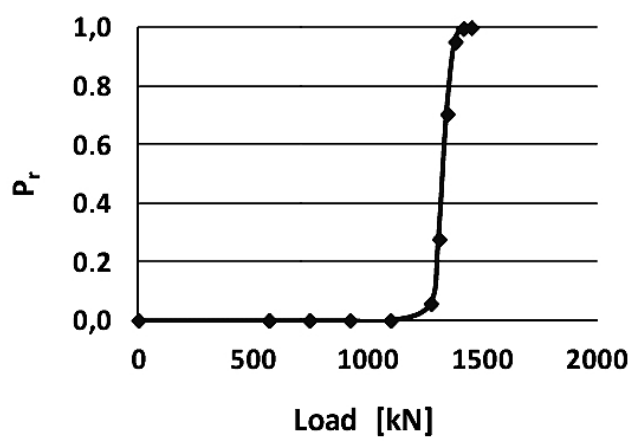

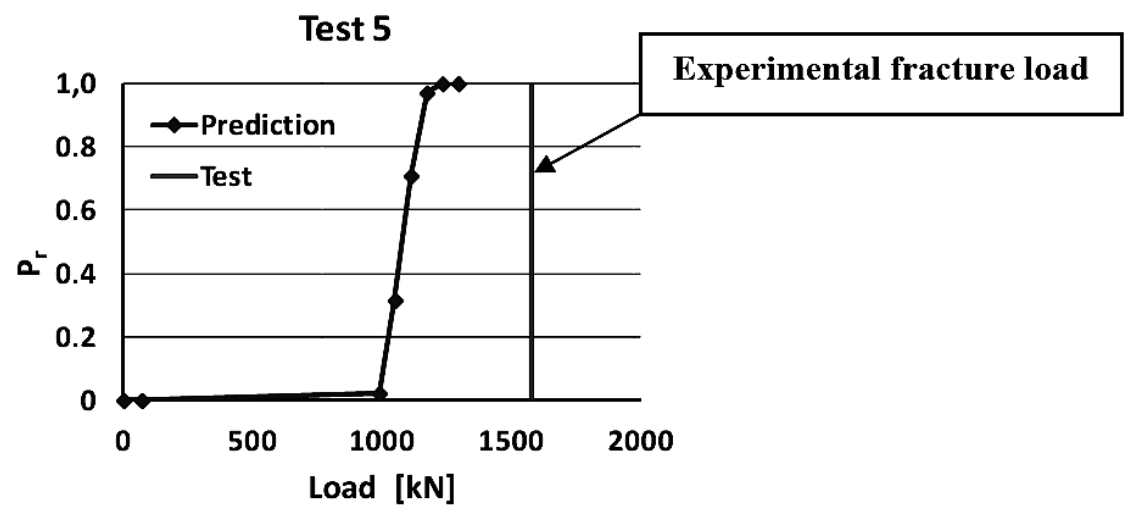

Fig. 8. Failure probability-load curves. 
the temperature $T=-150^{\circ} \mathrm{C}$. The vertical line in the diagram for Test 5 (Fig. 8) shows the fracture load from the experimental test $\left(F_{\text {fract }}=1578 \mathrm{kN}\right)$.

Conclusions. Elastic-plastic analyses of cruciform specimens made of RPV steel with a semi-elliptical crack were performed using isotropic hardening material law. Verification of the simulation was done by comparing different curves obtained from the experimental tests, such as load-deflexion curve, load-CMOD curve and CMOD-temperature curve. The cumulative probability of failure was determined by the modified Beremin model for all five experimental tests using a different criterion for the definition of the active plastic zone. In case of the Test 5 analysis, the fracture is predicted using the modified Beremin model. The method provides a lower value for the failure probability than the obtained experimental fracture load. Development of the method is currently in progress to obtain more accurate prediction.

\section{Р езюме}

Із використанням результатів експериментальних досліджень великогабаритних хрестоподібних зразків із реакторної сталі французького виробництва виконано скінченноелементне моделювання ефекту гарячого опресування за циклічного навантаження за схемами: навантаження-охолодження-руйнування i навантаження-охолодження-перехідний процес-руйнування. Для оцінки імовірності руйнування зразків використано модифіковану модель Береміна.

1. W. Lefevre, G. Barbier, R. Masson, and G. Rousselier, "A modified Beremin model to simulate the warm pre-stress effect," Nucl. Eng. Design, 216, 27-42 (2002).

2. R. Beleznai, G. B. Lenkey, and D. Lauerova, "Calibration of three-parameter Weibull stress model for 15Kh2NMFA RPV steel," J. Nucl. Mater., 406, 119-126 (2010). 